\title{
Concentrations of Chloride and Sodium in Groundwater in New Hampshire From 1960 Through 2011
}

\section{Median chloride concentrations were at least $1 \frac{1}{2}$ times higher and sodium concentrations at least 3 times higher between 2000-11 than in all previous decades.}

\section{Introduction}

Several studies from the 1970 s and more recently (for example, Hall (1975), Daley and others (2009), and Mullaney (2009)) have found that concentrations of chloride and sodium in groundwater in New Hampshire have increased during the past 50 years. Increases likely are related to road salt and other anthropogenic sources, such as septic systems, wastewater, and contamination from landfills and saltstorage areas. According to water-quality data reported to the New Hampshire Department of Environmental Services (NHDES), about 100 public water systems (5 percent) in 2010 had at least one groundwater sample with chloride concentrations that were equal to or exceeded the U.S. Environmental Protection Agency (USEPA) secondary maximum contaminant level (SMCL) of 250 milligrams per liter $(\mathrm{mg} / \mathrm{L})$ before the water was treated for public consumption. The SMCL for chloride is a measurement of potential cosmetic or aesthetic effects of chloride in water. High concentrations of chloride and sodium in drinkingwater sources can be costly to remove.

A new cooperative study between the U.S. Geological Survey (USGS) and the NHDES (Medalie, 2012) assessed chloride and sodium levels in groundwater in New Hampshire from the 1960s through 2011. The purpose of the study was to integrate all data on concentrations of chloride and sodium from groundwater in New Hampshire available from various Federal and State sources, including from the NHDES, the New Hamsphire Department of Health and Human Services, the USGS, and the U.S. Environmental Protection Agency (USEPA), for public and private (domestic) wells and to organize the data into a database. Medalie (2012) explained the many assumptions and limitations of disparate data

The amount of a substance present in a given volume of water is often expressed as a concentration in $\mathrm{mg} / \mathrm{L}$.

The U.S. Environmental Protection Agency drinking water regulations specify the following:

Chloride: SMCL of $250 \mathrm{mg} / \mathrm{L}$

Sodium: DWA for individuals on a sodium-restricted diet of $20 \mathrm{mg} / \mathrm{L}$

\section{Chloride}

1. Median concentrations of chloride in groundwate used out of the 41,500 chloride records assembled for this project.
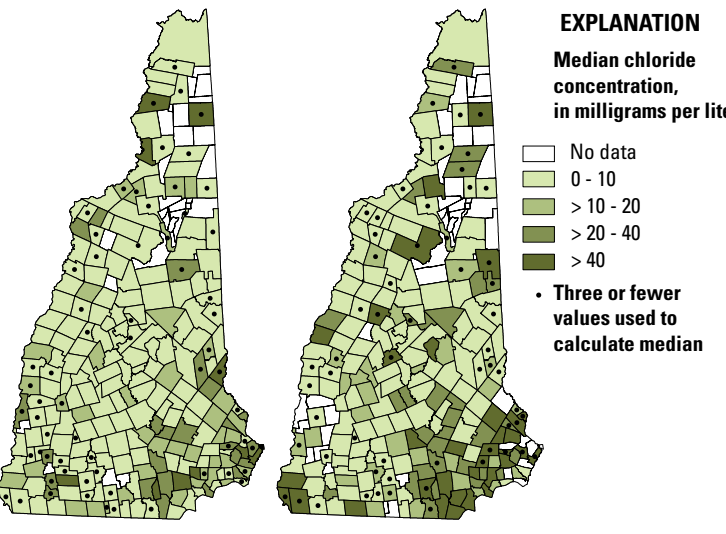

2005 that were collected to meet wide-ranging objectives. This fact sheet summarizes the most important findings of the data.

\section{Overview of Significant Findings}

Individual wells that had concentrations reported in both 1995 and 2005 were used to subset the data to show meaningful changes over time. The comparison of median concentrations of chloride (fig. 1) and sodium (fig. 2) by town for 1995 and 2005 shows a shift towards increased concentrations in 2005. The median is the middle value in the dataset after the data have been ordered by magnitude. Between 1995 and 2005, the number of towns with median concentrations of chloride greater than $20 \mathrm{mg} / \mathrm{L}$ almost doubled from 35 to 65 , and the number of towns with concentrations of chloride greater than $40 \mathrm{mg} / \mathrm{L}$ more than tripled from 10 to 34 . Over the same time span, the number of towns with concentrations of sodium greater than $10 \mathrm{mg} / \mathrm{L}$ increased from 89 to 114, and the number of towns with concentrations greater than $20 \mathrm{mg} / \mathrm{L}$ increased from 26 to 43 . The numbers themselves are not as important as their utility in describing increases over time.

Table 1 shows that the $17 \mathrm{mg} / \mathrm{L}$ median concentration of chloride in the 2000s was at least one and a half times higher than the median for all previous decades. The 90th percentile (highest 10 percent of values) of concentration for 2000-11 was higher than for all decades and double all the values for the 1980s and 1990s. Low concentrations among decades, shown by the 10th percentile (lowest 10 percent of values), cannot be compared because many of the reported values were below a reporting threshold (indicated with "<"). To compare data with different reporting thresholds, all values below the reporting threshold (censored values) were adjusted to the common value of $10 \mathrm{mg} / \mathrm{L}$, which was the highest censored value among the data.

Most of the percentiles of concentrations of sodium for data through the 1990s were less than $10 \mathrm{mg} / \mathrm{L}$; however, all the percentiles were greater than $10 \mathrm{mg} / \mathrm{L}$ in the 2000s. Between the 1990s and 2000s, all percentiles of concentrations of sodium increased - the median by more than a factor of three, and the 90th percentile by a factor of six. These data provide substantial evidence that sodium concentrations in New Hampshire groundwater for 2000-11 increased considerably from previous decades. 
Table 1. Summary statistics for chloride and sodium in groundwater in New Hampshire.

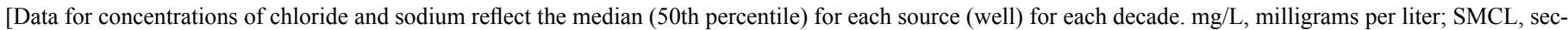
ondary maximum contaminant level; USEPA, U.S. Environmental Protection Agency; DWA, drinking water advisory; <, less than]

\begin{tabular}{|c|c|c|c|c|c|c|}
\hline Statistic $^{1}$ & 1960s & 1970s & 1980s & 1990s & $2000 s^{2}$ & All \\
\hline \multicolumn{7}{|c|}{ Chloride } \\
\hline \multicolumn{7}{|l|}{ Concentrations, in mg/L: } \\
\hline 10th percentile & $<10$ & $<10$ & $<10$ & $<10$ & $<10$ & $<10$ \\
\hline 50th percentile & 10 & 11 & 10 & $<10$ & 17 & $<10$ \\
\hline 90 th percentile & 88 & 77 & 60 & 61 & 122 & 79 \\
\hline Number of median observations & 114 & 402 & 2,227 & 2,503 & 1,671 & 6,917 \\
\hline Number censored & 0 & 159 & 640 & 831 & 102 & 1,732 \\
\hline Observations with concentrations higher than the $250 \mathrm{mg} / \mathrm{L} \mathrm{SMCL}^{3}$, in percent & 7 & 3 & 1 & 3 & 3 & 3 \\
\hline \multicolumn{7}{|c|}{ Sodium } \\
\hline Concentrations, in $\mathrm{mg} / \mathrm{L}$ : & & & & & & \\
\hline 10th percentile & NA & $<10$ & $<10$ & $<10$ & 19 & $<10$ \\
\hline 50 th percentile & NA & $<10$ & $<10$ & $<10$ & 30 & $<10$ \\
\hline 90th percentile & NA & $<10$ & $<10$ & 15 & 89 & 40 \\
\hline Number of median observations & NA & 183 & 1,616 & 2,542 & 1,785 & 6,126 \\
\hline Number censored & NA & 0 & 157 & 654 & 0 & 811 \\
\hline Observations with concentrations higher than the $20 \mathrm{mg} / \mathrm{L}$ USEPA DWA ${ }^{3}$, in percent & NA & 13 & 23 & 23 & 30 & 27 \\
\hline
\end{tabular}

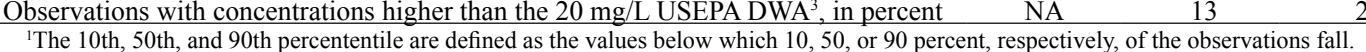

${ }^{2}$ Includes 2011.

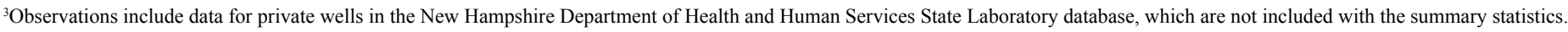

The percentage of observations with concentrations higher than the $20-\mathrm{mg} / \mathrm{L}$ USEPA drinking water advisory (DWA) for individuals on a sodium-restricted diet for sodium increased from 13 percent during the 1970 s to 30 percent during the 2000s. Higher concentrations of chloride and sodium in 2005 were especially pronounced in the southeastern part of the State (figs. 1 and 2).

\section{Selected References}

Daley, M.L., Potter, J.D., and McDowell, W.H., 2009, Salinization of urbanizing New Hampshire streams and groundwater-Effects of road salt and hydrologic variability: Journal of North American Benthological Society, v. 28, no. 4, p. 929-940.

Hall, F.R, 1975, Chloride in natural waters of New Hampshire, station bulletin 504, New Hampshire agricultural experiment station: Durham, New Hampshire, University of New Hampshire, 25 p.

Medalie, Laura, 2012, Temporal and spatial trends of chloride and sodium in groundwater in New Hampshire, 1960-2011: U.S. Geological Survey Open-File Report 2012-1236, 25 p., accessed January 31, 2013, at http://pubs.usgs.gov/of/2012/1236/.

Mullaney, J.R., Lorenz, D.L., and Arntson, A.D., 2009, Chloride in groundwater and surface water in areas underlain by the glacial aquifer system, northern United States: U.S. Geological Survey Scientific Investigations Report 2009-5086, 41 p., accessed January 31, 2013, at http://pubs.usgs.gov/of/2009/5086.
New Hampshire Department of Environmental Services, 2008, New Hampshire road salt reduction initiative: New Hampshire Department of Environmental Services, accessed January 31, 2013, at http://des. nh.gov/organization/divisions/water/ $\mathrm{wmb} / \mathrm{was} /$ salt-reduction-initiative/ index.htm.

New Hampshire Department of Environmental Services, 2010, Sodium and chloride in drinking water: New Hampshire Department of Environmental Services Environmental Fact Sheet WD-DWGB-3-17, 3 p., accessed January 31, 2013, at http:// des.nh.gov/organization/commissioner/pip/factsheets/dwgb/documents/dwgb-3-17.pdf.

\section{By Laura Medalie}

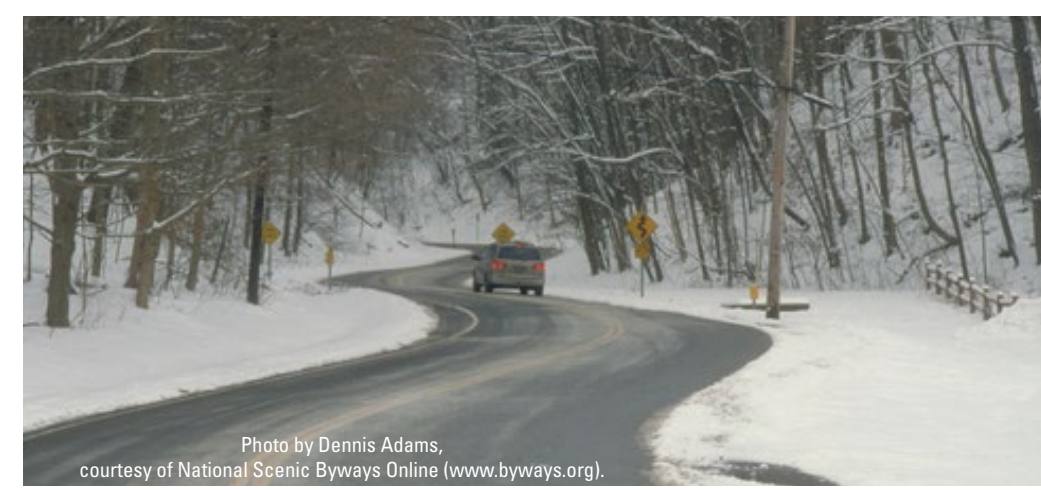

\section{For More Information, Contact:}

U.S. Geological Survey

New England Water Science Center, New Hampshire-Vermont Office 331 Commerce Way, Suite 2, Pembroke, NH 03275

http://nh.water.usgs.gov 